\title{
ASSESSMENT OF THE COMPOSITION AND THE VOLUME OF BIOGAS LIBERATION FROM AGRICULTURAL WASTES
}

\author{
G. Y. Jayasinghe, K. D. N. Weerasinghe, \& S. R. W. Pathiranage \\ Department of Agricultural Engineering, Faculty of Agriculture, \\ University of Ruhuna
}

Study was conducted in the Faculty of Agriculture, University of Ruhuna, Mapalana to assess the composition and the volume of biogas liberation pattern from different agricultural raw matcrials.

In the Sri Lankan batch type biogas generator (volume $\left.6 \mathrm{~m}^{3}\right)$, first batch of straw $(1000 \mathrm{~kg}$ ) was filled in September 1999 and second and third batch in October 2000, April 2001 respectively. It was revealcd that average gas production from the digester was $1.0 \mathrm{~m}^{3} /$ day with a peak value of $1.8 \mathrm{~m}^{3} /$ day. Total gas production during four and half month period of digestion was $166.85 \mathrm{~m}^{3}$. The maximum average methane percentage and the average lag phase during the digestion were $50 \%$ and 20 days respectively.

In order to assess the biogas liberation pattern and composition of each material, a laboratory test unit was designed using a $20 \mathrm{~L}$ plastic gallon as the digester and experiment was conducted using straw, cow dung and market garbage (vegetable) as raw materials. Gas volumes, $\mathrm{pH}$ value of slurry and methane percentage were measured while maintaining the temperature between $35^{\circ} \mathrm{C}-37^{\circ} \mathrm{C}$ using electric bulbs.

$\mathrm{N}, \mathrm{P}, \mathrm{K}$ compositions, $\mathrm{C} / \mathrm{N}$ ratio and dry matter percentages of different raw materials were analyzed. Total biogas libcrated per unit weight of dry matter was $8.15 \mathrm{~L}, 58.7 \mathrm{~L}$ and $15.797 \mathrm{~L}$ for dung, vegetable and straw respectively. The duration of digestion period was 55-60 days. Average methane percentages of the liberated gases were $53 \%, 54 \%$ and $50 \%$ for dung, vegetable and straw respectively. It was revealed that market garbage had the highest digestibility value, which had the highest gas production with high methane percentage.

Proceedings of the Eighth Annual Forestry and Environment Symposium 2002 of the Department of Forestry and Environmental Science, University of Sri Jayewardenepura, Sri Lanka 